\title{
Operating without operations: how is technology changing the role of the firm?
}

Christoph Breidbach, Sunmee Choi, Benjamin Ellway, Byron W. Keating, Katerina

Kormusheva, Christian Kowalkowski, Chiehyeon Lim and Paul Maglio

The self-archived postprint version of this journal article is available at Linköping University Institutional Repository (DiVA):

http:/ / urn.kb.se/ resolve?urn=urn:nbn:se:liu:diva- 152844

N.B.: When citing this work, cite the original publication.

Breidbach, C., Choi, S., Ellway, B., Keating, B. W., Kormusheva, K., Kowalkowski, C., Lim, C., Maglio, P., (2018), Operating without operations: how is technology changing the role of the firm?, J ournal of Service Management, 29(5), 809-833. https:// doi.org/ 10.1108/J OSM-05-2018-0127

Original publication available at:

https:// doi.org/ 10.1108/J OSM-05-2018-0127

Copyright: Emerald

http:// www.emeraldinsight.com/ 


\title{
OPERATING WITHOUT OPERATIONS: HOW IS TECHNOLOGY CHANGING THE ROLE OF THE FIRM?
}

\author{
Christoph F. Breidbach - University of Melbourne, Australia \\ Sunmee Choi - Yonsei University, Republic of Korea \\ Benjamin P. W. Ellway - University of Canberra, Australia \\ Byron W. Keating - Australian National University, Australia \\ Katerina Kormusheva - Australian National University, Australia \\ Christian Kowalkowski - Linköping University, Sweden, and Hanken School of \\ Economics, Finland \\ Chiehyeon Lim - Ulsan National Institute of Science and Technology, Republic of \\ Korea \\ Paul P. Maglio - UC Merced, USA \\ All authors contributed equally to this article.
}

July 30, 2018

Original article forthcoming in Journal of Service Mangement (2018)

Official publication: https://doi.org/10.1108/JOSM-05-2018-0127

This is a so-called personal version (author's manuscript as accepted for publishing after the review process but prior to final layout and copy editing) of the article. Readers are kindly asked to use the official publication in references.

Copyright: Emerald www.emerald.com 
OPERATING WITHOUT OPERATIONS:

HOW IS TECHNOLOGY CHANGING THE ROLE OF THE FIRM?

\begin{abstract}
Purpose: $\quad$ The history and future of service operations are analyzed, with the goal to identify key theoretical and technological advances, as well as fundamental themes that can help to imagine the future of service operations in 2050.
\end{abstract}

Approach: A review of the service operations literature was undertaken to inform a discussion regarding the role that technology will play in the future of service operations.

Findings: The future of service operations is framed in terms of three key themescomplexity, orchestration, and elasticity. The paper makes three contributions to the service science literature by: (1) reviewing key themes underpinning extant service operations research to frame future trajectories of service operations research; (2) elaborating a vision of service operations in 2050 based on history and technology; and (3) outlining a research agenda for future service operations.

Originality: Service operations in the next 30 years will be very different from what it was in the past 30 years. This paper differs from other review papers by identifying three key themes that will characterize and instill new insights into the future of service operations research.

Paper type: Conceptual paper.

Keywords: Operations management, operations strategy, service operations, service systems, technology. 


\section{OPERATING WITHOUT OPERATIONS: HOW IS TECHNOLOGY CHANGING THE ROLE OF THE FIRM?}

A visit to Disneyland Tokyo in $2050 \ldots$

Yuriko meets her friends at 8:55am on Saturday, just before the gates open. At 9:00am, they walk through the gates together, and receive a schedule of activities that has been tailored to their individual and collective emotional state over the past week, as well as their mutual interest in Japanese Manga. They always find available seats, just enough for the group. They never queue at any attraction. Following the schedule they received, they enjoy the morning parade, run into friends from school, chat over shared lunch, and pose for photos with their favourite characters. At the end of the visit day, they bow to each other and turn to leave.

Yuriko turns off the 5-D simulator in her house. She does not need provide feedback on her experience as her emotional and cognitive responses have already been captured and uploaded to all of her social channels and her publicly available medical profile. She receives notification that the cost for the day at Disneyland Tokyo Virtual has already been deducted from her bank balance as her satisfaction levels had exceeded the company's minimum guaranteed levels.

Yuriko receives an invitation to join her friends again next week. Unfortunately she has another appointment at that time and will not be able to attend, but that does not have to impact on her friends. The system gives her the option of allowing her virtual avatar to participate instead. She agrees, and schedules a time to review the highlights after the event. The system learns from her reactions to the highlights, and tweaks her virtual profile, making it ever more indistinguishable from the real her. She pauses and wonders whether she should have let her friends know that it was not really her, but then, she notices that one of her friends posted an image to one of her social channels of her at lunch with another group of friends while she was supposed to be at Disneyland Tokyo. She smiles and wonders what her great grandparents would have thought of how firms operate without operations in 2050. 
Service operations research has been concerned, since its inception, with backstage processes that support and coordinate front-stage processes to deliver customer-centred services (Leffingwell, 1917). Evolving as a major sub-field of operations management, early contributions conceptualized service operations in terms of production processes (Chase, 1978), and subsequent efforts have focused on optimizing and improving the efficiency and effectiveness of these processes (e.g., Maister, 1985; Larson, 1987, Heskett, 1997; Norris and Bockelmann; Roth and Menor, 2003). More recently, the introduction of service science (Spohrer and Maglio, 2005), service-dominant logic (Vargo and Lusch, 2004), and servitization (Neely, 2008) has recast service operations in a different light; rather than focusing on exploiting production capabilities for efficiency gains, service operations is increasingly concerned with value creation in the context of coordinated firm, customer, and system or ecosystem activities (Chase and Apte, 2007). A turning point has now been reached in the understanding of service operations. However, to make a leap to 2050, it is necessary to better understand the evolving needs and capabilities of all stakeholders within a service system, and within the broader context of a business ecosystem, to shape arrangements of stakeholders to take advantage of available capabilities for mutual value creation (Lusch, 2011).

Technological advances, such as smart sensor technologies, high speed wireless communications, robotics, and artificial intelligence have created unprecedented levels of efficiency and extraordinary opportunities for innovation in general, and technology-enabled value co-creation, in service businesses in particular (Roth and Menor, 2003; Chase and Apte, 2007; Breidbach and Maglio 2016; Huang and Rust, 2018). Instant and global informationsharing, the internet of things, big data analytics, deep learning, and other current technologies already help actors within service systems to better anticipate customer needs and provide faster, more accurate service solutions that create more overall value than ever 
before (Peters et al., 2016; Antons and Breidbach 2018). Looking to the future, the impact of new technologies - such as virtual reality, quantum computing, and other innovations - is not easy to predict. Nevertheless, technological advances are expected to unlock previously unimagined opportunities for value creation, but in doing so, these advances are also likely to raise important questions regarding the role of humans in the future of service operations (Ransbotham et al., 2017), and indeed within society more broadly (Espinel et al., 2015). The increasing trend toward the fusion of people and technology, ubiquitous storage and connectivity, more effective use of big data and artificial intelligence, and digitization of matter are important for the future of service (Larson, 2016; Maglio, Kwan and Spohrer, 2015; Breidbach et al. 2013).

Against this backdrop of transformations, this paper discusses the history and future of service operations, aiming to identify key theoretical and technological advances along with fundamental themes that can help to imagine the future of service operations in 2050. In the future, key service management issues will relate to orchestration of activities and resources, complexity of interactions among varied stakeholders, and the elasticity and governance of systems (and systems of systems), particularly in the context of data analytics, deep learning, and autonomous technologies. Service operations in the next 30 years will be very different from what it was in the past 30 years. The challenge is to focus not so much on technologies, but on operational issues facing firms, and how these will change. In the end, three contributions to the service science literature are provided: (1) a review of the big ideas of service operations research as a starting point for framing the future of service operations research; (2) elaboration of a vision of service operations in 2050 based on history and technology; and (3) an outline of a research agenda for future service operations. 


\section{Looking back at service operations research}

The literature on service operations is vast, with dedicated literature reviews including detailed classifications of service operations research (Machuca et al., 2007; Smith et al., 2007), historical accounts of the emergence and development of key ideas (Chase and Apte, 2007; Heineke and Davis, 2007; Victorino et al., 2018), as well as more critical reviews that identified gaps as a basis for outlining research agendas (Bretthauer, 2004; Chase, 1996; Hill et al., 2002; Jonhston, 1999; Roth and Menor, 2003; Field et al., 2018).

In the first half of the $20^{\text {th }}$ century, the main approach to service operations was to apply principles of scientific management, for instance, to find routines that could be remembered and learned to improve efficiency (Leffingwell, 1917) or to manage customer variability on a case-by-case basis (Leffingwell and Robinson, 1943). At the same time, a number of firms introduced service innovations aimed at improving operations and profitability: Disney’s innovations including managing customer total experience by offering carefully designed themed lands, training employees through Disney University, casting employees as actors to play specific parts, and providing employees with rigid scripts to follow in interacting with customers; and Holiday Inn's innovations included standardization of the customer lodging experience throughout its multiple hotel locations (Chase and Apte, 2007). Later, McDonald’s pioneered the production-line approach to service, incorporating (1) standardization and reduction in the variety of products, (2) simplification, standardization and automation of processes so that workers with limited skills and training can reliably produce quality products and deliver high quality service; (3) monitoring and control of process performance (Norris and Bockelmann, 2000).

In the 1960's, interest turned to the economics of service, for instance, with studies exploring the growth of productivity and in comparing manufacturing and service industries (e.g., Baumol and Bowen, 1965; Fuchs, 1965, 1968). In the 1970’s focus shifted to customer 
experience and service design, particularly by adapting methods from manufacturing (e.g., Levitt, 1972; Shostack, 1977, 1984), and to categorizing services by specific attributes and dimensions (see Sasser 1976). Chase’s (1978) customer contact theory grew out of this trend toward categorizing services, in this case by amount of customer interaction with the firm; later work added the use of technology into customer contact theory (Froehle and Roth, 2004). In the 1980's others took different approaches to categorizing services, for instance by intensity of firm-side labour (Schemner, 1983), or by the nature of the service and its delivery (Lovelock, 1983).

There was also a new focus on queuing, moving from a mathematical approach to a psychological one in which expectations and perceptions matter more than absolute wait times (Maister, 1985; Larson, 1987), and on tools to match service capacity and service demand, such as yield management (Kimes, 1989). In the 1990’s, the service profit chain connected employee satisfaction to customer satisfaction (Heskett et al., 1997), recovering from service failure depended on empowering service workers (Hart, 1990), and minimizing failures or errors relied on automated methods in delivery (Chase and Stewart, 1994). Over time, it seemed that that technology was enabling services to become more and more disaggregated, even on a global scale, requiring substantial communication and coordination (Apte and Mason, 1998), and providing opportunity for mass customization of service experiences (Pine and Gilmore, 1998). Ultimately, lean management and related ideas were applied to service (Ahlstrom, 2004; Womack and Jones, 2005), as was behavioural operations, which take account of human cognitive and other limitations (Chase and Apte 2007; Gino and Pisano, 2008), and product-service systems and servitization, which emphasize the coordination of goods and services (Baines and Lightfoot, 2013; Kowalkowski and Ulaga, 2017; Mont, 2002) and which represents the movement from material-intensive manufacturing to information-intensive services (Karmarkar et al., 2015) and knowledge- 
based services (Pemeder et al., 2003). More recently, service operations have been viewed as a part of value co-creative processes of customer, provider, and their interaction (e.g., Payne, Storbacka and Frow, 2008; Sampson, 2012).

\section{Key themes in service operations research}

In a recent review in the Journal of Service Management, Victorino et al. (2018) noted that reviews ought to adopt a more interdisciplinary approach to understanding service operations from related fields such as marketing, human resources, and information systems, reflecting a more service science perspective (Spohrer and Maglio, 2008). In what follows, themes are identified that last over time and span disciplines, aiming to identify the meta-level phenomena that the field of service operations has been built on, and will continue to be built on, as well as the related assumptions that underpin them. Identifying these phenomena and corresponding assumptions is critical to understand the future of what service operations may look like. There is irrefutable evidence that changes in phenomena often challenge prior assumptions, which in turn prompt disruption and give rise to the emergence of unforeseen trends of changes. For example, new technologies are changing market structures and challenging prior assumptions about power distribution in service systems (Fehrer et al., 2018), enabling new business models that challenge the role and importance of stakeholders in service systems (Andreassen et al., 2018), and more fundamentally may represent an inflection point for the service sector similar to the industrial revolution in manufacturing (Wirtz et al., 2018). Given the interdisciplinary nature of service operations, it is also important to highlight that marketing, human resources, and information systems, as well as service science, all draw upon theoretical knowledge outside of the business and management discipline, such as psychology, sociology, engineering, as well as science, technology, and society studies (Maglio and Breidbach 2014). The paper begins by identifying the key roles 
and relationships of people and technology in service operations, incorporating examples from Field et al. (2018), which also explored the future of service operations research.

\section{People in service operations}

Involving people, particularly customers, in the production or delivery process is one of the defining features of service operations research (Chase and Apte, 2007). Customers present challenges for service operations that do not exist in manufacturing because people create uncertainty and unpredictability, which must be managed or controlled (Leffingwell and Robson, 1943). Acknowledging challenges caused by the presence of people in service operations is reflected in many articles, and perhaps best captured in the title, "Where does the customer fit in a service operation?” (Chase, 1978). Attempts to control human behaviour in service operations have extended to employees, through efforts to script and standardize their actions (e.g., Disney and McDonalds). The conceptualisation of human involvement increased in sophistication through the investigation of psychological aspects of human behaviour in relation to queuing (Maister, 1985; Larson, 1987), through a more humanistic approach to employees that highlighted the importance of their satisfaction to successful service operations (Heskett, 1997), and most recently, through the application of behavioural science principles to understand human decision-making, especially the role of biases, the limits of rationality, and the importance of social norms (Chase and Dasu, 2001). Groups or organisations of people may also be considered behavioural entities (Gino and Pisano, 2008), which, through collective social norms and emergent patterns of behaviour, extend the focus of service operations beyond the conventional individual actor or firm.

Three assumptions that have been central to investigations of service operations may not hold in the future. First is the assumption that customers bring uncertainty and unpredictability to service operations. Customers arrive for service at different times and at different rates, customers have different skills and different expectations, and customers have 
different preferences (Frei and Harker, 1999). But will this assumption necessarily hold true in the future? Given the proliferation in technologies aimed at understanding and predicting human actions, particularly collection and use of data and deep learning, it is questionable if uncertainty will remain a key problem. And if a need to respond to uncertainty does persist, it is clear that these technologies are also capable of accommodating high levels of variability and heterogeneity.

The second key assumption about the role of people in service operations is that there are two basic categories of people, employees and customers. Yet even three decades ago this distinction was being challenged by the argument that customers should be viewed as "partial employees” (Mills and Morris, 1984). More recently, service-dominant logic refers to “actors” in interactions for resource integration and value co-creation, rather than to customers and employees (Vargo and Lusch, 2016). Field et al. (2018) acknowledge the importance of reflecting upon the roles and responsibilities of customers and employees, but this paper questions whether these categories will be the most useful or most appropriate for understanding the role of people in service operations in the future. For example, the emergence of the sharing economy has already blurred boundaries between the roles of actors in service ecosystems (Breidbach and Brodie 2017). As a case in point, an individual could simultaneously be an employee of a sharing economy platform provider (i.e., Uber), be a customer by using the ride-sharing application, or even provide the service by becoming a driver. The tendency for roles to be reconfigured holds true in other service contexts, for example in ' $\mathrm{M}$ ' and ' $\mathrm{T}$ ' business models where the importance and role of middlemen is being challenged (Andreassen et al., 2018).

The third assumption is that people represent the most important actors in service operations (Chase, 1978; 1983). In the subsequent sections of this review, attention is given to the expanded role of technology, and question the conceptualisation of people and 
technology as separate actors. Assumptions about the nature of human involvement in service have been observed to change over time, for instance, from rational decision making to behavioural operations (Gino and Pisano, 2008) and from the individual actors to collective units of behavioural analysis (Li and Choi, 2009). Will future characteristics of human involvement in service operations also need to be revised? Will it be necessary to develop new theoretical frameworks to capture the changing nature of the unit of analysis (i.e., from individuals to groups to systems)? Given that heterogeneity arising from human involvement has occupied service operations researchers throughout history, any change to this fundamental operating assumption would represent a critical shift in the focus of service operations research and practice. This assumption regarding human involvement is already beginning to erode in relation to employees through their replacement with service robots, a trend that is only likely to increase in the future (Chui et al., 2016; Wirtz et al. 2018).

\section{The role of technology}

Broadly speaking, technology may be defined as the application of a scientific principle to solve human problems or satisfy human needs (Arthur, 2009). Using this view, this paper distinguishes between technology as techniques or principles, and technology as machinery or systems. Technologies used in service operations are often thought of as tools to manage or control, to predict, or to design service processes. The most notable conceptualization of technology in service operations is Froehle and Roth's (2004) extension of the customer contact model according to the different roles technology can take. Yet the pace of technological change, exemplified by machine learning and quantum computing, as well as innovations such as the blockchain and cryptocurrencies, suggests that technology will present numerous opportunities and challenges to service firms in the future.

The emergence of these new technologies may render old ones obsolete, and may lead to the development of new technologies. Moreover, access to technology may put customers 
rather than firms in control of how technology is used to facilitate services. This raises numerous questions. Will existing taxonomies regarding the nature and role of technology be sufficient? Will customer contact take new forms based upon newly emerging roles for technology, or on new ways of accessing technology? This transformation is already starting to take place in hospitality operations, for example, where sophisticated yield management systems analyse operational, environmental, and customer feedback data in real-time to predict, create and deliver better tailored customer experiences (Kandampully et al., 2016).

\section{The relationship between people and technology}

There is a clear distinction made between people and technology in the prior literature on service operations. Technology is implemented to control or enable human action. By contrast, some have highlighted how viewing technology as enabling and constraining human action is just one of a number of different ways to conceptualize the relationship between people and technology (Ellway and Walsham, 2015; Orlikowski and Scott, 2008). In particular, sociomaterial approaches to understanding technology in organizations and society rejects the separation of people and technology as discrete entities, emphasizing instead intraactions through the fusing of the two. This is not simply an abstract philosophical consideration. It has immediate consequences for the nature of real world phenomena. For example, Orlikowski and Scott (2015) examine the changing nature of service in the hospitality industry using a socio-material lens to show that users of Internet services are inseparable from the algorithms used, noting also the difficulty in studying these phenomena and understanding their effects given this inseparability. The emergence of new phenomena such as digital twins and automated social presence in technology-enabled services (Bolton et al., 2018) is a further example of how the conceptualisation of the relationship between technology and people may need to be rethought.

There are two clear implications for the future of service operations. First, this review 
reveals the implicit, and usually taken-for-granted assumption in prior service operations theorizing humans and technology as separate and discrete entities; and second, the review suggests that it may be necessary to position technology as an equally important actor, alongside humans, in the study of service operations in the future. A summary of the key findings from the literature review, as well as the key questions that it raises for the future of service operations research is provided in Table 1.

"Insert Table 1 here”

\section{Looking forward: Future of service operations}

Service operations have changed dramatically over the past 100 years. Whereas firms once controlled operations largely internally, with well-defined relationships to outside suppliers and other stakeholders, modern service providers orchestrate the actions of varied stakeholders both inside and outside the firm (Normann and Ramirez, 1993). No longer is it possible to consider service in terms of simple dyadic interactions and relationships - service occurs in a complex system or ecosystem of multiple stakeholders (Maglio, Vargo, Caswell and Spohrer, 2009; Vargo and Lusch, 2011). No longer are traditional notions of ownership or firm-based value creation relevant as resources are routinely shared among individuals and firms, creating the need for flexible or elastic relationships (Dustdar et al., 2011). The boundaries between providers and receivers (rather than firms and customers) are blurring, and the boundaries between people and technologies are blurring (Moldovan, Copil and Dustdar, 2017). In this section, three emerging themes from the literature that are likely to inform the future of service operations research are described: complexity, orchestration, and elasticity. 


\section{Complexity}

A system is "a combination of interacting elements organized to achieve one or more stated purposes” (ISO/IEC, 2008). Human-designed systems, such as mechanical systems, have well-defined architectures and well-understood operational mechanisms. For other systems, parts may be designed, but the systems themselves, such as cities, may evolve with architectures and operational mechanisms emerging over time. Service systems are an example of such an open system, where configurations of people, information, organizations, and technologies need to operate together for the creation of mutual value (Maglio et al., 2009). Service systems tend to fall between fully-designed and fully-emergent systems, and provide the basic abstraction for service operations management (Spohrer and Maglio, 2008).

As with many other systems, service systems are complex (Tien, 2008; Briscoe et al., 2012), which means these systems are intrinsically difficult to model and manage because of interactions among their elements, and because the behaviour of the system cannot simply be inferred from behaviour of its elements (Bar-Yam, 2003). This is true of service systems in transportation (Pelletier et al., 2011), healthcare (Tien, 2009), telecommuncations (Ellway, 2016), energy (Strasser et al., 2015), hospitality (Kandampully et al., 2015), and manufacturing industries (Meier et al., 2010). For example, new technology-enabled services are increasing the complexity of the customer experience and connecting previously distinct digital, physical and social realms (Bolton et la., 2018), service work may increasingly be nested within complex self-adjusting service work ecosystems (Subramony et al., 2018), and ongoing changes in service ecosystem contexta trigger innovation which in turn may lead to further complexity (Edvarsson et al., 2018).

Unlike the connectivity among elements in fully-designed systems, the sociotechnical nature of service systems contributes to the intangible and emergent nature of the 
connections among its elements (Maglio et al., 2015). Accordingly, one difficulty in operating complex service systems is the lack of capability to monitor and manage complexity in an automatic or semi-automatic manner. Recent technological advances, however, have contributed to enhancing the connections among system elements, the collection of data from elements, and computation and communications among elements for efficient decision making within modern complex service systems (Lim and Maglio, 2018). These advances assist with monitoring and managing the complexity of service systems for value creation (Maglio and Lim, 2018). Examples include monitoring and prevention of automobile problems (Lim et al., 2015) and human diseases (Lim et al., 2018).

Enhanced connectivity is facilitated through new objects (e.g., devices and servers) and new organizations (e.g., data management and analytics companies), which add further to the complexity of service systems (Breidbach et al., 2013). In this regard, another difficulty in operating modern complex service systems is the necessity for intermediaries, either individuals, organizations, or technologies, to facilitate reliable, trustworthy and seamless interactions and operations within system networks (Breidbach et al., 2016). Examples of such intermediaries are banks and IT platform companies. Banks connect investors and investees and manage financial transaction data, and IT platform companies connect users and organizations and manage huge amounts of interaction data (Breidbach and Ranjan, 2017).

Despite enhanced connectivity in modern service systems, the security and privacy of interactions within systems often needs to be managed by intermediary organizations or technologies (Lim et al., 2017), thereby possibly generating inefficiencies in operations and unnecessary transaction costs. However, emergent technologies such as blockchain can reduce such inefficiencies and transaction costs by enabling direct and secure interactions among elements in a service system, and minimizing the roles and authorities of traditional 
intermediaries (Risius and Spohrer, 2017). From its initial application to cryptocurrencies (Nakamoto, 2008), it is possible to see how this disruptive innovation can substantially reduce the complexity and inefficiency in service systems, and dramatically change the landscape of service operations in financial (Guo and Liang, 2016), energy (Hukkinen et al., 2017), consumer electronics (Lee and Pilkington, 2017), manufacturing (Abeyratne and Monfared, 2016), and other industries (Hull, 2017; Iansiti and Lakhani, 2017).

In the new context of peer-to-peer direct value co-creation enabled by connection, and with emerging technologies such as blockchain, the important question in managing complex service systems becomes “where does the firm fit in a service operation?” rather than "where does the customer fit in a service operation?” (Chase, 1978). Traditionally in disconnected networks with centralized intermediaries, customers depend on the economic activities of firms, and improving the operations of firms was important. However, in the upcoming connected, decentralized networks, such dependency is minimal; firms should position themselves in the network of the economic activities of customers, and facilitating value cocreation without operations will be crucial.

How can future researchers approach this new context of complex service systems? Future research needs to start by defining and describing the nature of complexity. In particular, how will this affect the design and operation of service ecosystems? How elastic, decentralized, and autonomous will the service systems of the future be? And how will manage orchestration and governance across increasingly complex and dynamic networks of collaborators be managed to co-create value in the future?

\section{Orchestration}

Service orchestrators seek to respond to the increased complexity of service operations by facilitating resource integration, and thereby value co-creation between other interdependent 
actors within complex service systems (Breidbach et al., 2016). The role of service orchestrators (usually human or organizational actors), can be distinguished from the practice of service orchestration, which may be accomplished by technology. In this way, the concept of service orchestration resembles network orchestration, which is defined as the process of assembling and managing an inter-organizational network to achieve a collective goal (Paquin and Howard-Grenville, 2013), in which the legitimacy of different roles are only established when accepted by the other network members (Müller-Seitz, 2012).

Value creation is always at the core of service systems, and thus management of operations within complex human-centred service systems requires an understanding of individual values and multiple stakeholder perspectives (Maglio et al., 2015) - even when the needs of stakeholders are hard to model and study. The complexity of service systems is reflected in the physical, informational, and interpersonal interactions among people, organizations, and technologies (Glushko, 2010; Sampson, 2012), where these interactions and the associated trade-offs that are made by the different stakeholders combine to form a value constellation network for a service system (Kieliszewski et al., 2008; Patrício et al., 2011).

Value creation in such service systems is also complicated by the multi-level, multiagent, and multi-disciplinary nature of such interactions (Spohrer et al., 2007; Joore and Brezet, 2015). Service systems have at least three levels of analysis: service ecosystems (Lusch et al., 2016), business systems (Maglio et al., 2009), and automated service functions (Erl, 2004). Service ecosystems involve dynamic interactions among different agents (Lee et al., 2012), such as suppliers, customers, and intermediaries, who perform specific processes within the systems (Payne et al., 2008; Lim et al., 2012). Different disciplines have varying scopes and foci in studying the same service systems. For example, marketing has a customer-oriented perspective on service systems (Chandler and Lusch, 2015), information 
systems takes a resource utilization viewpoint to service systems (Lusch and Nambisan, 2015), and operations management emphasizes the modelling of service systems through tools such as stochastic and combinatorial optimization models (Hillier, 2015).

Rather than individual human actors, business marketing and organizational studies typically refer to organizational stakeholders (lead firms, hub firms, etc.) when discussing orchestration activities. Research on orchestration of intentionally created networks assumes that the lead firm is able to purposefully influence and manage its network (Dhanaraj and Parkhe, 2006; Hinterhuber, 2002; Lorenzoni and Lipparini, 1999; Müller-Seitz, 2012), that is, intentional networking and orchestrating value through deliberate activity. It resonates with studies of networks that adopt an actor-defined perspective, such that a central network actor strives to configure its business relationships through networking activities (e.g., Jarillo, 1988; Perks et al., 2017).

Dedicated employee roles intended to orchestrate value co-creation have been considered in several service contexts, such as retailing (Bradford and Sherry, 2013), real estate (Natti et al., 2014), and consulting (Breidbach and Maglio, 2016). However, none of these prior contributions have explicitly described or explored the role of service orchestrators, or the practice of service orchestration. Breidbach et al. (2016) found that the introduction of case managers, a type of service orchestrator increasingly common in hospitals for example, was associated with greater patient satisfaction and staff perceptions of patients' involvement in value co-creation processes as well as with higher process efficiency and staff productivity in clinical departments.

Beyond the role of the orchestrator, organization studies have also identified several orchestration processes that contribute to value creation within complex service systems, including the management of knowledge mobility, innovation appropriability, innovation leverage, innovation coherence, network membership, and network stability (Dhanaraj and 
Parkhe, 2006; Nambisan and Sawhney, 2011). Effective orchestration requires processes that enhance the ease with which stakeholders can access the knowledge and expertise of other stakeholders (Kale, Singh, and Perlmutter, 2000), promote the equitable distribution of costs as well as benefits (Teece, 2000), and preserve the stability of the network by encouraging stakeholders to consider and respect the needs of other stakeholders (Kenis and Knoke, 2002). The cost of leveraging knowledge and resources increases as the network grows (Iansiti and Levien, 2004), requiring effective processes to ensure openness and transparency in the sharing of information (Lorenzoni and Lipparini, 1999), and for managing the coherence and coordination across stakeholders to reduce inefficiencies and ineffectiveness in the acquisition and application of new knowledge (Bullinger, Auernhammer, and Gomeringer, 2004).

Future research needs to focus on expanding the evidence base. Conclusive empirical and theoretical insights, as well as normative guidelines regarding the effective orchestration and facilitation of value co-creation processes in complex service systems, are required to realize the practical value of orchestration. Such guidance has been unavailable to date (Bowen 2015; Ostrom et al. 2015). This research should explore coordination mechanisms other than service orchestrators in complex service ecosystems. This could be digital or cognitive assistance systems, such as IBM’s Watson (Breidbach et al., 2016). In particular, it is necessary to better understand how the emergence of service ecosystems could be orchestrated and facilitated (Breidbach and Brodie, 2017), and how orchestration mechanisms depend on the underlying platform characteristics, such as novelty and complexity. Also, future research needs to disentangle how actors other than the lead service orchestrator can appropriate value (Perks et al., 2017). 


\section{Elasticity}

Elasticity refers to the extent to which the relationships among people and things within a service ecosystem are interdependent, exchangeable, and flexible. Elasticity can be viewed in terms of three core dimensions—resource elasticity, cost elasticity, and quality elasticity (Dustdar et al., 2011). Resource elasticity concerns processes used to allocate human and computing resources to achieve desired needs. Cost elasticity concerns the trade-off between cost and efficiency. Quality elasticity concerns decisions that contribute to the effectiveness of the ecosystem given the available resources.

Elasticity seeks to resolve tensions among human and computational actors as each strives to achieve individual goals. Requiring new methods and techniques to capture, manage, and adapt to find mutually acceptable compromises, Moldovan, Copil and Dustdar (2017) argue that elasticity represents a new approach to computing, where the goal is to optimize a complex system as a whole rather than optimizing individual processes. This approach views smart devices, hybrid computing, and adaptive, autonomous and intelligent systems as agents for value creation among actors, with traditional boundaries among computers, people, and things increasingly blurred.

A key consideration for elastic systems relates to the challenge of governance via task definition and allocation. According to Moldovan et al. (2017), the design and management of complex elastic systems requires new models of orchestration and governance, where the roles of computers, people and things are seen as being far more fluid and better able to capture the particularities and capabilities of the various elements of the network. For example, a recent study of governance within a cloud-based complex system involving a network of Internet-enabled objects revealed the need for an adaptive dynamic approach to governance that reflects inherent uncertainty associated with decision making over the lifecycle of a complex system (Nastic, Copil, Truong, and Dustdar, 2015). Uncertainties 
resulting from novel interactions of things, network elements, cloud resources, and humans create challenges for governance of complex service systems. In response, the authors introduce a declarative policy language to simplify the development of uncertainty- and elasticity-aware governance strategies.

This work builds on prior research in the area of cyber-physical systems, which has attempted, in part, to recast computing in terms of the interface between the cyber and physical worlds, emphasizing the need to move beyond the human computing view where humans conceive and direct computers to control resources. While humans are likely to play a role in setting the initial rules (e.g., declarative policy language), elasticity among connected and heterogeneous service systems is likely to be managed and controlled in the future by computing agents that will use and adapt such rules to manage the increasing complexity of cloud-based and cloud-supported service systems, and to realize existing and new and unexpected value propositions (Ray, 2016). In this sense, the service system becomes a platform for enabling new value propositions via the elastic reconfiguration of existing resources and systems using adaptive and dynamic rule-based governance frameworks (Copil et al., 2013).

Future research is needed to better understand how to manage the relationships among computers, people and things. The insights provided by this new research will no doubt drive new approaches to control and governance (e.g., computers programming computers), which will in turn, give rise to important ethical considerations. It is also timely to consider the ultimate purpose of such systems. Where much of the attention of the computing literature has been on efficiency in information transfer and use, future research in the field of computing will need to accommodate elasticity in the purpose of the systems being created, particularly as these systems seek to resolve the views of actors with very different expectations. The insights from other disciplines have an important role to play, with insights 
from the complementary fields such as marketing and operations management helping to broaden the perspective of computing and resolve the inherent tensions described earlier.

\section{How is technology changing the role of the firm in service operations?}

From the discussion so far, it is clear that the key to the past and the future of service operations is technology. In the past, there were well-defined roles for people and technology and firms mainly managed and controlled technologies available for use in service operations. Now, this is all changing. In the future, service operations will need to respond to greater levels of variability, heterogeneity, changing and diffuse roles of actors, and the need to better integrate humans and technology. Future service systems, will, accordingly, need to facilitate the flexible or elastic orchestration of people and technologies in complex arrangements for value creation. Consider how recent technologies help people make decisions, take action, and assess value. It is not a big leap to imagine a future in which technology assumes even greater prominence, blurring the role of the firm in service operations.

Autonomous service systems provide an illustration of how technology is set to redefine service operations in the future. Defined as systems that operate largely without human participation and intervention (Chui et al., 2016), autonomous service systems rely on five technology factors for creating value: (1) connection between things and people, (2) collection of data for context awareness, (3) computation in the cloud, (4) communications by wireless technologies, and (5) control of human and object actions (Lim and Maglio, 2018; Maglio and Lim, 2018). Figure 1 provides a graphical summary of how these five technology factors combine to impact value co-creation among the three key actors in autonomous service systems—-people, providers, and things. 


\section{"Insert Figure 1 here”}

Connected things include tangible goods directly used by customers and dedicated infrastructures generally required by customers and providers; these goods and infrastructures can be connected to other things. Collected data include condition traces of engineered systems, event logs of business processes, health and behavioural records of people, and biological signals of people and animals; physical and social sensing from things and people within a service system produce data that indicate behaviours and operations of people, operations and condition management of organizations and things, and interactions within a service system. Computational processes involve the use of algorithms and knowledge to support decision-making; computation is a prerequisite for data and information communication in a connected network because these processes transform raw data into standardized data or information that enable machine-understandable data or humanunderstandable information.

Control in autonomous service systems includes typical machine-to-machine actuation, human-to-machine control, and recently available automation of human-to-human transactions and workflows enabled by smart contracts—-self-executing scripts in the blockchain network of different parties; control in traditional and autonomous service systems can be distinguished in terms of variability, with the former reducing variability (e.g., ATMs covering limited options) and the latter accommodating variability (e.g., AI-based financial services investing by themselves). Technologies communicate with one another, people communicate with one another, people and technologies communicate; building on technologies for connection, collection, and computation, control and communication factors enable interactions among different aspects of any system. Any sociotechnical service system involves value co-creation, which brings different stakeholders together to produce a mutually valued outcome. Encounters 
for value co-creation increase as people, organizations, information, and technologies become connected more tightly; informational or intellectual resources for value co-creation increase as systems collect and compute quality data; and the frequency and intensity of value cocreation increases as systems control and communicate efficiently and effectively with one another.

Examples of future autonomous service systems based on these five technology factors include autonomous homes, buildings, transportation, logistics, farming, and healthcare systems (Lim and Maglio, 2018; Maglio and Lim, 2018). An autonomous home, for instance, can be defined as a service system that automates various value co-creating activities (e.g., lighting, cooking, temperature control, etc.) for home owners through connection, collection, computation, control, and communications. The autonomous home can simplify the life of home owners by learning about their preferences, and then orchestrating various value creating activites in response to the changing and competing needs of different stakeholders.

An autonomous apartment in the not-to-distant future could connect to external systems to capture information on government environmental policies, and information available from external suppliers about their good and services, and then synthesize this information with information collected on home owner behavior using a network of sensors to compute the optimal combination of value co-creating activities to ensure that net benefits are achieved (e.g., household specific environmental targets), while also meeting the home owner's lifestyle and consumption preferences. Depending on the system policies (which could be set by the user, the system, or some third party, and could be fixed or dynamic), the autonomous service system could be responsible for monitoring sensors and controlling activities such as heating and cooling levels, turning appliances on and off, and even communicating with suppliers to negotiate and arrange better supply agreements. And though 
this example demonstrates how a simple autonomous service system can orchestrate elastic solutions to the moderately complex challenge of environmental management within a single household, the same technological infrastructure could be scaled to afford automation and optimization at the building, community, city or even country levels.

Unfortunately, most of the prior research on autonomous service systems has focused mainly on the technology, with less on the roles and relationships with people, organizations, and the impact on value creation (Lim and Maglio, 2018). The framework depicted in Figure 1, and the three emergent themes proposed here, can provide useful tools for informing the design and management of fully or partially automated service systems in the future.

\section{Discussion}

The three themes of complexity, orchestration, and elasticity emerged from the review of service operations literature, and observations of the changing role of technology in service operations. Consider service system complexity. Unpredictability and uncertainty of individual customers may be less important than unpredictability of entire service systems. Technologies in the service system may not be entirely (or even mainly) within the control of individual firms, but rather may represent characteristics of constantly evolving service systems. Complexity is inextricably linked to the relationship between technology and people, and the almost unfathomable pace of change suggests that isolating individual interactions between technology and people will be increasingly more difficult, and that assemblages of multiple actors may be increasingly important.

Increasing complexity implies that orchestration will become an imperative. Is it too early to suggest that orchestration will replace efficiency as the key objective of service operations? Probably, especially as service orchestrators represent just one actor among many in service systems. This point of course shows again the importance of the changing 
categories of actors in service operations. Given that the role of service orchestrators has already been demonstrated, it is possible to speculate what other roles or categories of actors might emerge.

The importance of elasticity also arises from complexity and orchestration. It immediately forces us to reconsider the overriding importance and objective of efficiency of service operations. And it may represent a new design decision, replacing the original choices outlined by Chase (1978) concerning decoupling and interdependence. It may also require us to consider different dimensions of elasticity or different levels of elasticity for different conditions in and across service systems. Alternatively, the complexity of service systems and of connections between service firms, just like technology, may not represent a choice or decision to be made by individual firms, but rather, configurations to be monitored, influenced, and adapted to by firms. It is in this way, that the future will require firms to operate without operations - in the traditional sense. Table 2 provides a summary of key research issues relating to these three emergent themes.

"Insert Table 2 here”

The first theoretical implication lies at the marketing-operations interface for service management: In the new context of peer-to-peer direct value co-creation enabled by technologies of connection, collection, computation, control, and communications, boundaries between the service provider and customer are fluid and vary case-by-case. In this new future fluid context, the difference between marketing and operations perspectives will not be that clear. Payne et al. (2008) showed that management of value co-creation in service requires an integrative approach to consider both provider-side and customer-side. Traditionally, the former has been investigated mainly in the operations management field 
whereas the latter has been investigated mainly in marketing (Roth and Menor, 2003). However, it has been difficult to integrate the two fields in the literature, though high connectivity is essential in practice.

In the future fluid context, the two sides (and indeed the many stakeholders) will not be distinct and thus synchronization and harmonization of the two fields will be a must. Service research should provide a foundation for marketing-oriented operations management in autonomous service systems, such as human process management in the connected network, and the same for operations-oriented marketing management, such as customer experience in a real-time adaptive service environment. Of course reconciliation of the two fields is still many years away because of the variety and differences in data from the customer and provider processes (Tang, 2010). Nonetheless, the current work contributes to the literature by providing an original and unified viewpoint that connects marketing and operations management for effective management of fluid autonomous service systems.

The second theoretical implication concerns how institutions and technologies can encapsulate and automate activities to facilitate and enhance value co-creation in future autonomous service operations: Institutions define rules and practices by which individuals and groups behave and coordinate behaviour (e.g., North, 1990). Technologies make use of natural phenomena to serve human purposes (Arthur, 2009). Together these constitute foundational components of all service systems, arrangements of people, technologies, information, and organizations that create mutual value through joint action and interaction (Maglio and Spohrer, 2013). Specifically, both institutions and technologies incorporate routine knowledge and behaviours, usually simplifying tasks and freeing up resources for deliberate action, and often leading to innovation (Vargo et al., 2015). In fact, one axiom of the service-dominant logic is that "value co-creation is coordinated through actor-generated institutions and institutional arrangements” (Vargo and Lusch, 2016). Yet it is not always 
clear what should be institutionalized or automated in future autonomous service operations, or whether and when these will improve operational performance (Maglio, 2015). Little research addresses design questions of what should be institutionalized or automated, and under what conditions. Yet, given recognition that service systems play a fundamental role in human wellbeing, and that service inclusion represents a moral (Fisk et al., 2018), and even ethical (Asadi-Someh et al. 2016) imperative, design questions represent an important opportunity for service operations researchers to contribute to this important area.

The third theoretical implication relates to understanding data-based value co-creation mechanisms: The design of a service system operating without operations requires several fundamental understandings, such as understanding of the data-based value co-creation mechanism. Studies on data-based value creation mechanisms are required to autonomously operate service systems with data (cf. Lim and Maglio, 2018). A value creation mechanism refers to a set of activities and resources, used by service customer and provider to jointly perform particular functions (Payne et al., 2008; Lim and Kim, 2014). A prerequisite to improve existing services or design new services for customers is a fundamental understanding of the value creation mechanisms in the context of the specific service in question (Patrício et al., 2011). Service researchers have discussed the notion of value cocreation intensively (e.g., Galvagno and Dalli, 2014; Grönroos and Voima, 2013). However, with few exceptions (e.g., Saarijärvi, 2011; Saarijärvi et al., 2014), the review revealed a surprising lack of work directed at providing frameworks to help organizations manage databased value creation or co-creation, despite its significance in the future fluid context of autonomous and elastic service systems.

There are also potential practical or managerial implications. For one, increasing automation, particularly of information actions, suggests that competitiveness will depend more on non-information actions. Human actions in service systems can be categorized as 
information, physical, and interpersonal actions (Apte and Mason, 1995), and the automation of these actions has evolved from automated teller machines of banking services to warehouse robots of shipping services and robots for emotional and frontline interactions. What happens when the all firms have access to almost limitless data and almost limitless ability to analyse it? How will firms differentiate themselves? What will be the new core competencies? Technological advances in connection, collection, computation, control, and communications provide service companies with numerous opportunities for operating without operations.

Opportunities may lie not with the technology itself, but with the extended ability to enable an autonomous value co-creation mechanism. Ironically, with complete automation, technology may not matter much; service system design may matter more. For example, the core utility of blockchain technology is the ability to "program" the interactions within a service network and to "design" the value co-creation mechanism in service system, as is currently done for electronic and mechanical systems.

\section{Conclusion}

More conventional reviews of service operations research, encompassing the field in breadth and depth, provide invaluable resources for scholars to trace the historical development of the discipline as well as provide detailed frameworks for subsequent service operations research (e.g., Roth and Menor, 2003; Chase and Apte, 2007; Victorino et al., 2018). By contrast, the approach taken here has been to identify broad themes that tie together service operations research, question whether assumptions inherent within them will remain, and provide evidence for already emerging trends in service and service systems. Some of the ideas, issues, and questions articulated may well not come to pass. But accurately predicting the future or providing irresistibly familiar classifications, frameworks, or research agendas was 
not the motivation.

Rather, in this paper the aim was to draw attention to what might change further into the future. No one knows what service operations research will be in 2050 or what challenges service firms will face in managing their operations in 2050. Predicting with a high level of certainty is a risky trade, but the aim was to stimulate debate in the field and set out a new research agenda to help guide the field forward. For managers and firms, the main implication of this work is that service businesses ought to get ready to respond to the new emerging themes of complexity, orchestration, and elasticity. In the end, it is hoped only to trigger some ideas about what the practical challenges and academic questions in 2050 might be. 


\section{References}

Abeyratne, S. A., and Monfared, R. P. (2016). Blockchain ready manufacturing supply chain using distributed ledger. Loughborough, UK: Loughborough University.

Ahlstrom, P. (2004). Lean service operations: translating lean production principles to service operations. International Journal of Services Technology and Management, 5(5-6), 545-564.

Andreassen, T. W., Lervik-Olsen, L., Snyder, H., van Riel, A. C. R., Sweeney, J. C. and Van Vaerenbergh, Y. (2018). Business model innovation and value-creation: The triadic way. Journal of Service Management, this issue.

Antons, D. and C. F. Breidbach (2018). Big data, big insights: Advancing service innovation and design with machine learning. Journal of Service Research, 21 (1), 17-39.

Apte, U. M., \& Mason, R. O. (1995). Global disaggregation of information-intensive services. Management science, 41(7), 1250-1262.

Arthur, W. B. (2009). The nature of technology: What it is and how it evolves. New York, NY: Simon and Schuster.

Asadi-Someh, I., Breidbach, C. F., Davern, M. and Shanks, G. (2016). Ethical implications of big data analytics. Proceedings of the $24^{\text {th }}$ European Conference on Information Systems (ECIS), Istanbul, Turkey.

Baines, T. and Lightfoot, H. (2013). Made to serve: How manufacturers can compete through servitization and product service systems. Chichester, UK: Wiley.

Bar-Yam, Y. (2003). Dynamics of complex systems. Boulder, CO: Westview Press.

Baumol, W. J., \& Bowen, W. G. (1965). On the performing arts: the anatomy of their economic problems. The American economic review, 55(1/2), 495-502.

Bilgihan, A., Kandampully, J., \& Zhang, T. (2016). Towards a unified customer experience in online shopping environments: Antecedents and outcomes. International Journal of Quality and Service Sciences, 8(1), 102-119. 
Bolton, R. N., McColl-Kennedy, J., R., Cheung, L., Gallan, A. S., Orsingher, C., Witell, L. and Zaki, M.(2018). Customer experience challenges: Bringing together digital, physical and social realms, Journal of Service Magamenet, this issue.

Bowen, D. E. (2016). The changing role of employees in service theory and practice: An interdisciplinary view. Human Resource Management Review, 26(1), 4-13.

Bradford, T. W., \& Sherry Jr, J. F. (2013). Orchestrating rituals through retailers: An examination of gift registry. Journal of Retailing, 89(2), 158-175.

Breidbach, C. F., Kolb, D. G., and Srinivasan, A. (2013). Connectivity in service systems: Does technology-enablement impact the ability of a service system to co-create value? Journal of Service Research, 16 (3), 428-441.

Breidbach, C. F., and P. P. Maglio (2016). Technology-enabled value co-creation: An empirical analysis of actors, resources, and practices. Industrial Marketing Management, 56, 73-85.

Breidbach, C. F., Antons, D., and Salge, T. O. (2016). Seamless service? On the role and impact of service orchestrators in human-centered service systems. Journal of Service Research, 19 (4), 458-476.

Breidbach, C. F., and Brodie, R. J. (2017). Engagement platforms in the sharing economy: Conceptual foundations and research directions. Journal of Service Theory and Practice, 27 (4), 761-777.

Breidbach, C. F. and Ranjan, S. (2017). How do fintech service platforms facilitate value cocreation? An analysis of twitter data. Proceedings of the $38^{\text {th }}$ International Conference on Information Systems (ICIS), South Korea.

Bretthauer, K. M. (2004). Service management. Decision Sciences, 35(3), 325-332.

Briscoe, G., Keränen, K., and Parry, G. (2012). Understanding complex service systems through different lenses: An overview. European Management Journal, 30 (5), 418-426. 
Bullinger, H. J., Auernhammer, K., and Gomeringer, A. (2004). Managing innovation networks in the knowledge-driven economy. International Journal of Production Research, 42 (17), 33373353.

Chandler, J. D., and Lusch, R. F. (2015). Service systems: a broadened framework and research agenda on value propositions, engagement, and service experience. Journal of Service Research, 18 (1), 6-22.

Chase, R. B. (1978). Where does the customer fit in a service operation?. Harvard Business Review, 56 (6), 137-142.

Chase, R.B. (1983). The customer contact approach to services: theoretical bases and practical extensions. Operations Research 21 (4), 698-705.

Chase, R. B. (1996). The mall is my factory: reflections of a service junkie. Production and Operations Management, 5(4), 298-308.

Chase, R. B., and Apte, U. M. (2007). A history of research in service operations: What's the big idea? Journal of Operations Management, 25 (2), 375-386.

Chase, R.B., and Dasu, S. (2001). Want to perfect your company’s service? Use behavioral science. Harvard Business Review 78 (6), 78-85.

Chase, R.B., Stewart, D.M., 1994. Make your service fail-safe. Sloan Management Review 35 (3), $35-44$.

Chui, M., Manyika, J., and Miremadi, M. (2016). Where machines could replace humans - and where they can’t (yet). McKinsley Quarterly, July.

Copil, G., Moldovan, D., Truong, H. L., and Dustdar, S. (2013). Multi-level elasticity control of cloud services. Proceedings of the International Conference on Service-Oriented Computing, 429-436.

Dhanaraj, C., \& Parkhe, A. (2006). Orchestrating innovation networks. Academy of management review, 31(3), 659-669. 
Dustdar, S., Guo, Y., Satzger, B., \& Truong, H. L. (2011). Principles of elastic processes. IEEE Internet Computing, 15(5), 66-71.

Edvardsson, B., Frow, P. Jaakkola, E., Keiningham, T., Koskela-Huotari, K., Mele, C. and Tombs, A. (2018). Examining how context change foster service innovation, Journal of Service Management, this issue.

Ellway, B. (2016). Design vs practice: How problematic call routing and rerouting restructures the call centre service system. International Journal of Operations \& Production Management, 36(4), 408-428.

Ellway, B., and Walsham, G. (2015). A doxa - informed practice analysis: reflexivity and representations, technology and action. 25 (2), 133-160.

Erl, T. (2004). Service-oriented architecture: a field guide to integrating XML and web services. Upper Saddle River, NJ: Prentice hall.

Espinel, V., O’Halloran, D., Brynjolfsson, E., and O’Sullivan, D. (2015). Survey Report: Deep Shift: Technology Tipping Points and Societal Impact. In World Economic Forum, September.

Fehrer, J. A. Benoit, S., Aksoy, L., Baker, T. L., Bell, S. J., Brodie, R. J. and Marimuthu, M. (2018). Future scenarios of the collaborative economy: Centrally orchestrated, social bubbles or decentralized autonomous? Journal of Service Management, this issue.

Field, J. M., Victorino, L., Buell, R. W., Dixon, M. J., Meyer Goldstein, S., Menor, L. J., ... and Zhang, J. J. (2018). Service operations: what's next?. Journal of Service Management, 29 (1), 55-97.

Fisk, R. P., Dean, A. M., Alkire (née Nasr), L., Alison Joubert, A., Previte, J., Robertson, N. and Rosenbaum, M. (2018). Design for service inclusion: Creating inclusive service systems by 2050, Journal of Service Management, this issue. 
Frei, F.X., and Harker, P.T. (1999). Measuring the efficiency of service delivery processes: an application to retail banking. Journal of service research 1 (4), 300-312.

Froehle, C. M., \& Roth, A. V. (2004). New measurement scales for evaluating perceptions of the technology-mediated customer service experience. Journal of Operations Management, 22(1), $1-21$.

Fuchs, V., 1965. The Growing Importance of the Service Industries, Occasional Paper \#96. National Bureau of Economic Research,

New York.

Fuchs, V., 1968. The Service Economy. National Bureau of Economic Research, New York.

Galvagno, M., \& Dalli, D. (2014). Theory of value co-creation: a systematic literature review. Managing Service Quality, 24(6), 643-683.

Gino, F., and Pisano, G. (2008). Toward a theory of behavioral operations. Manufacturing and Service Operations Management, 10 (4), 676-691.

Glushko, R. J. (2010). Seven contexts for service system design. In Handbook of service science (219-249). Boston, MA: Springer.

Grönroos, C. and Voima, P. (2013), Critical Service Logic: Making Sense of Value Creation and Co-Creation, Journal of the Academy of Marketing Science, 41 (2), 133-150.

Guo, Y., and Liang, C. (2016). Blockchain application and outlook in the banking industry. Financial Innovation, 2(1), 24.

Hart, C.W.L., 1988. The power of unconditional service guarantee. Harvard Business Review 66 (4), 54-62

Hart, C.W.L., Heskett, J.L., Sasser, W.E., 1990. The profitable act of service recovery. Harvard Business Review 68 (4), 148-156

Heineke, J., \& Davis, M. M. (2007). The emergence of service operations management as an academic discipline. Journal of Operations Management, 25(2), 364-374. 
Heskett, J.L., Sasser Jr., W.E., and Schlesinger, L.A., 1997. The Service Profit Chain. New York, NY: Free Press.

Hill, A. V., Collier, D. A., Froehle, C. M., Goodale, J. C., Metters, R. D., \& Verma, R. (2002). Research opportunities in service process design. Journal of Operations Management, 20(2), 189-202.

Hillier, F. S. (2015). Introduction to operations research. Singapore: Tata McGraw-Hill Education.

Hinterhuber, A. (2002). Value chain orchestration in action and the case of the global agrochemical industry. Long range planning, 35(6), 615-635.

Hukkinen, T., Mattila, J., Ilomäki, J., and Seppälä, T. (2017). A Blockchain Application in Energy (No. 71). The Research Institute of the Finnish Economy. Available at https://EconPapers.repec.org/RePEc:rif:report:71.

Hull, R. (2017, June). Blockchain: Distributed Event-based Processing in a Data-Centric World. Proceedings of the 11th ACM International Conference on Distributed and Event-based Systems, 2-4.

Huang, M-H., and Rust, R. T. (2018). Artificial intelligence in service. Journal of Service Research, OnlineFirst.

Iansiti, M., and Lakhani, K. R. (2017). The Truth About Blockchain. Harvard Business Review, 95(1), 118-127.

Iansiti, M., and Levien, R. (2004). The keystone advantage. Boston, MA: Harvard Business School Press.

ISO/IEC (2008), Systems and software engineering-system life cycle processes, ISO/IEC 15288. Jarillo, J. C. (1988). On strategic networks. Strategic management journal, 9(1), 31-41. Johnston, R. (1999). Service operations management: return to roots. International Journal of Operations \& Production Management, 19(2), 104-124. 
Joore, P., and Brezet, H. (2015). A Multilevel Design Model: the mutual relationship between product-service system development and societal change processes. Journal of Cleaner Production, 97 (Jun), 92-105.

Kale, P., Singh, H., and Perlmutter, H. (2000). Learning and protection of proprietary assets in strategic alliances: Building relational capital. Strategic Management Journal, 21 (3), 217237.

Kandampully, J., Keating, B. W., Kim, B., Mattila, A. S., and Solnet, D. (2014). Service research in the hospitality literature: insights from a systematic review. Cornell Hospitality Quarterly, 55 (3), 287-299.

Karmarkar, U. (2015). OM forum—-the service and information economy: research opportunities. Manufacturing \& Service Operations Management, 17(2), 136-141.

Kenis, P., and Knoke, D. (2002). How organizational field networks shape interorganizational tieformation rates. Academy of Management Review, 27 (2), 275-293.

Kieliszewski, C. A., Maglio, P. P., and Cefkin, M. (2012). On modeling value constellations to understand complex service system interactions. European Management Journal, 30 (5), 438450.

Kimes, S.E., 1989. Yield management: a tool for capacity-constrained service firms. Journal of Operations Management 8 (4), 348-363.

Kowalkowski, C. and Ulaga, W. (2017), Service Strategy in Action: A Practical Guide for Growing Your B2B Service and Solution Business. Scottsdale, AZ: Service Strategy Press.

Larson, R.C., 1987. Perspectives on queues: social justice and the psychology of queuing. Operations Research 35 (6), 895-905

Larson, R. C. (2016). Smart service systems: Bridging the silos. Service Science, 8 (4), 359-367.

Larsson, R., \& Bowen, D. E. (1989). Organization and customer: managing design and coordination of services. Academy of Management Review, 14(2), 213-233. 
Lee, H. L., Padmanabhan, V., and Whang, S. (1997). The bullwhip effect in supply chains. Sloan Management Review, 38 (3), 93.

Lee, J. H., and Pilkington, M. (2017). How the Blockchain Revolution Will Reshape the Consumer Electronics Industry [Future Directions]. IEEE Consumer Electronics Magazine, 6 (3), 19-23.

Lee, S., Geum, Y., Lee, H., and Park, Y. (2012). Dynamic and multidimensional measurement of product-service system (PSS) sustainability: a triple bottom line (TBL)-based system dynamics approach. Journal of Cleaner Production, 32 (Sep), 173-182.

Leffingwell, W. H. (1917). Scientific Office Management, a Report of Application of the Taylor System of Scientific Management to Offices. AW Shaw Company.

Leffingwell, W.H., and Robinson, E.M. (1943). Textbook of Office Management (2nd ed). New York, NY: McGraw-Hill Book Company.

Levitt, T., 1970. The industrialization of service. Harvard Business Review 48 (5), 63-74.

Levitt, T., 1972. Production line approach to services. Harvard Business Review 50 (5), 32-43.

Li, M. E. I., and Choi, T. Y. (2009). Triads in services outsourcing: Bridge, bridge decay and bridge transfer. Journal of Supply Chain Management, 45 (3), 27-39.

Lim, C., Kim, K. H., Kim, M. J., Kim, K. J., Heo, J. Y., and Maglio, P. P. (2018). From data to value: a nine-factor framework for data-based value creation in information-intensive services. International Journal of Information Management, 39 (Apr), 121-135.

Lim, C. H., Kim, K. J., Hong, Y. S., and Park, K. (2012). PSS Board: a structured tool for product-service system process visualization. Journal of Cleaner Production, 37 (Dec), 4253.

Lim, C. H., Kim, M. J., Heo, J. Y., and Kim, K. J. (2015). Design of informatics-based services in manufacturing industries: case studies using large vehicle-related databases. Journal of Intelligent Manufacturing, Online First. 
Lim, C., Kim, M. J., Kim, K. H., Kim, K. J., and Maglio, P. P. (2017). Using data to advance service: managerial issues and theoretical implications from action research. Journal of Service Theory and Practice, Online First.

Lim, C., and Maglio, P. P (2018). Data-driven understanding of smart service systems through text mining. Service Science, Forthcoming.

Lorenzoni, G., and Lipparini, A. (1999). The leveraging of interfirm relationships as a distinctive organizational capability: a longitudinal study. Strategic Management Journal, 20 (4), 317338.

Lovelock, C. H. (1983). Classifying services to gain strategic marketing insights. The Journal of Marketing, 9-20.

Lusch, R. F. (2011). Reframing supply chain management: a service-dominant logic perspective. Journal of Supply Chain Management, 47 (1), 14-18.

Lusch, R. F., and Nambisan, S. (2015). Service innovation: A service-dominant logic perspective. MIS Quarterly, 39 (1), 155-175.

Lusch, R. F., Vargo, S. L., and Gustafsson, A. (2016). Fostering a trans-disciplinary perspectives of service ecosystems. Journal of Business Research, 69 (8), 2957-2963.

Machuca, J. A., del Mar Gonzalez-Zamora, M., \& Aguilar-Escobar, V. G. (2007). Service operations management research. Journal of Operations Management, 25(3), 585-603.

Maglio, P. P., Kwan, S. J. and Spohrer, J. (2015). Toward a research agenda for human-centered service system innovation. Service Science, 7(1), 1-10.

Maglio, P. P., and Lim, C. (2018). On the impact of autonomous technologies on human-centered service systems. In Handbook of service dominant logic, SAGE, Forthcoming.

Maglio, P. P., and Lim, C. (2016). Some thoughts on how institutions and technologies can encapsulate and automate activities to facilitate and enhance value co creation. Forum on Markets and Marketing. 
Maglio, P. P., and Breidbach, C. F. (2014). Service science: Toward systematic service system innovation. INFORMS Tutorials Series, Bridging Data and Decisions, 161-170.

Maglio, P.P., Vargo, S.L., Caswell, N. and Spohrer, J. (2009). The service system is the basic abstraction of service science. Information Systems and e-Business Management, 7 (4), 395406.

Maister, D. H. (1984). The psychology of waiting lines. Boston, MA: Harvard Business School.

Maister, D. H., \& Lovelock, C. H. (1982). Managing facilitator services. Sloan Management Review, 23(4), 19.

Meier, H., Roy, R., and Seliger, G. (2010). Industrial product-service systems-IPS 2. CIRP Annals-Manufacturing Technology, 59 (2), 607-627.

Mills, P. K., and Morris, J. H. (1986). Clients as “partial” employees of service organizations: Role development in client participation. Academy of Management Review, 11 (4), 726-735.

Moldovan, D., Copil, G, Dustdar, S. (2017). Elastic systems: Towards cyber-physical ecosystems of people, processes, and things. Computer Standards and Interfaces. Available at http://www.sciencedirect.com/science/article/pii/S092054891630232X.

Mont, O. K. (2002). Clarifying the concept of product-service system. Journal of cleaner production, 10(3), 237-245.

Müller - Seitz, G. (2012). Leadership in interorganizational networks: a literature review and suggestions for future research. International Journal of Management Reviews, 14(4), 428443.

Nakamoto, S. (2008). Bitcoin: A peer-to-peer electronic cash system. Available at https://bitcoin.org/bitcoin.pdf.

Nambisan, S., \& Sawhney, M. (2011). Orchestration processes in network-centric innovation: Evidence from the field. Academy of management perspectives, 25(3), 40-57. 
Nastic, S., Copil, G., Truong, H. L., and Dustdar, S. (2015). Governing elastic IoT cloud systems under uncertainty. Proceedings of the 7th IEEE International Conference on Cloud Computing Technology and Science (CloudCom), 131-138.

Nätti, S., Pekkarinen, S., Hartikka, A., \& Holappa, T. (2014). The intermediator role in value cocreation within a triadic business service relationship. Industrial Marketing Management, 43(6), 977-984.

Neely, A. (2008). Exploring the financial consequences of the servitization of manufacturing. Operations Management Research 1 (2), 103-118.

Norris, F., Bockelmann, C., 2000. The New York Times Century of Business. McGraw-Hill, New York, NY.

Normann, R. and Ramirez, R. (1993). From value chain to value constellation: Designing interactive strategy. Harvard Business Review, 71 (4), 65 - 77.

North D. C. 1990. Institutions, institutional change and economic performance. New York: Cambridge University Press. Google Scholar

Orlikowski, W. J., \& Scott, S. V. (2008). 10 sociomateriality: challenging the separation of technology, work and organization. The academy of management annals, 2(1), 433-474.

Ostrom, A. L., Parasuraman, A., Bowen, D. E., Patricio, L., \& Voss, C. A. (2015). Service research priorities in a rapidly changing context. Journal of Service Research, 18(2), 127-159.

Patrício, L., Fisk, R. P., Falcão e Cunha, J., and Constantine, L. (2011). Multilevel service design: from customer value constellation to service experience blueprinting. Journal of Service Research, 14 (2), 180-200.

Payne, A. F., Storbacka, K., and Frow, P. (2008). Managing the cocreation of value. Journal of the Academy of Marketing Science, 36 (1), 83-96.

Paquin, R. L., \& Howard-Grenville, J. (2013). Blind dates and arranged marriages: Longitudinal processes of network orchestration. Organization Studies, 34(11), 1623-1653. 
Pelletier, M. P., Trépanier, M., and Morency, C. (2011). Smart card data use in public transit: A literature review. Transportation Research Part C: Emerging Technologies, 19 (4), 557-568.

Peneder, M., Kaniovski, S., \& Dachs, B. (2003). What follows tertiarisation? Structural change and the role of knowledge-based services. The Service Industries Journal, 23(2), 47-66.

Perks, H., Kowalkowski, C., Witell, L., and Gustafsson, A. (2017). Network orchestration for value platform development. Industrial Marketing Management, 67, 106-121.

Peters, C., Maglio, P., Badinelli, R., Harmon, R. R., Maull, R., Spohrer, J., Tuunanen, T., Vargo, S., Welser, J, Demirkan, H., and Griffith, T. L. (2016). Emerging digital frontiers for service innovation. Communications of the Association for Information Systems: CAIS, 39, online.

Pine, B. J., \& Gilmore, J. H. (1999). The experience economy: work is theatre \& every business a stage. Harvard Business Press.

Ransbotham, S., Kiron, D., Gerbert, P., and Reeves, M. (2017). Reshaping Business with Artificial Intelligence: Closing the Gap Between Ambition and Action. MIT Sloan Management Review, 59(1), separate report.

Ray, P. P. (2016). Creating Values out of Internet of Things. Journal of Computer Networks and Communications, article 1, DOI: 10.1155/2016/1579460.

Risius, M., and Spohrer, K. (2017). A Blockchain Research Framework. Business and Information Systems Engineering, 59 (6), 1-25.

Roth, A. V., and Menor, L. J. (2003). Insights into service operations management: a research agenda. Production and Operations Management, 12 (2), 145-164.

Saarijärvi, H. (2011). Customer value co-creation through reverse use of customer data. PhD dissertation, Tampere University. Tampere University Press.

Saarijärvi, H., Grönroos, C., and Kuusela, H. (2014). Reverse use of customer data: implications for service-based business models. Journal of Services Marketing, 28(7), 529-537. 
Sampson, S. E. (2012). Visualizing service operations. Journal of Service Research, 15 (2), 182198.

Sasser, W. E. (1976). Match supply and demand in service industries. Harvard Business Review, 54(6), 133-140.

Schmenner, R. W. (1986). How can service businesses survive and prosper?. Sloan Management Review (1986-1998), 27(3), 21.

Shostack, G.L., 1977. Breaking free from product marketing. Journal of Marketing 41, 73-80.

Shostack, G.L., 1984. Designing services that deliver. Harvard Business Review 62 (1), 133-139.

Smith, J. S., Karwan, K. R., \& Markland, R. E. (2007). A note on the growth of research in service operations management. Production and Operations Management, 16(6), 780-790.

Spohrer, J., and Maglio, P.P. (2005). The emergence of service science. IBM Almaden Research Center.

Spohrer, J., and Maglio, P. P. (2008). The emergence of service science: Toward systematic service innovations to accelerate co-creation of value. Production and Operations Management, 17 (3), 238-246.

Spohrer, J., Maglio, P. P., Bailey, J., and Gruhl, D. (2007). Steps toward a science of service systems. Computer, 40 (1), DOI: 10.1109/MC.2007.33.

Strasser, T., Andrén, F., Kathan, J., Cecati, C., Buccella, C., Siano, P., Leitão, P., Zhabelova, G., Vyatkin, V., Vrba, P., and Mař́k, V. (2015). A review of architectures and concepts for intelligence in future electric energy systems. IEEE Transactions on Industrial Electronics, 62 (4), 2424-2438.

Subramony, M., Solnet, D., Groth, M., Hartley, N., Kim, P., Yagil, D., and Golubovskaya (2018). Service work in 2050: A work ecosystems perspective, Journal of Service Management, this issue. 
Tang, C. S. (2010). A review of marketing-operations interface models: From co-existence to coordination and collaboration. International Journal of Production Economics, 125 (1), 2240.

Teece, D. J. (2000). Managing intellectual capital: Organizational, strategic, and policy dimensions. OUP Oxford.

Tien, J. M. (2008). On integration and adaptation in complex service systems. Journal of Systems Science and Systems Engineering, 17 (4), 385-415.

Tien, J. M., and Goldschmidt-Clermont, P. J. (2009). Healthcare: A complex service system. Journal of Systems Science and Systems Engineering, 18 (3), 257-282.

Vargo, S. L., and Lusch, R. F. (2004). Evolving to a new dominant logic for marketing. Journal of Marketing, 68 (1), 1-17.

Vargo, S. L., and Lusch, R. F. (2011). It's all B2B... and beyond: Toward a systems perspective of the market. Industrial Marketing Management, 40 (2), 181-187.

Vargo, S. L., and Lusch, R. F. (2016). Institutions and axioms: an extension and update of service-dominant logic. Journal of the Academy of Marketing Science, 44, 5-23.

Victorino, L., Field, J. M., Buell, R. W., Dixon, M. J., Meyer Goldstein, S., Menor, L. J., ... and Zhang, J. J. (2018). Service operations: what have we learned?. Journal of Service Management, 29 (1), 39-54.

Womack, J. P., \& Jones, D. T. (2005). Lean consumption. Harvard Business Review, 83(3), 5868.

Wirtz, J., Patterson, P., Kunz, W., Gruber, T., Nhat Lu, V., Paluch, S., and Martins, A. (2018) Service robots in the front line: Will it be a Brave New World? Journal of Service Management, this issue. 
Table 1. Future of Service Operations Research

\begin{tabular}{|l|l|l|l|}
\hline Theme & Past & Present & Future \\
\hline People in service operations & $\begin{array}{l}\text { Service operations reduce } \\
\text { uncertainty of rational } \\
\text { human decision makers. }\end{array}$ & $\begin{array}{l}\text { Service operations capture and } \\
\text { respond to heterogeneity (e.g., } \\
\text { behavioral economics) reflected } \\
\text { in the decisions of humans with } \\
\text { bounded rationality. }\end{array}$ & $\begin{array}{l}\text { Can the delivery of services be truly automated, or is } \\
\text { the human element and customer variability always } \\
\text { going to be central to service operations? } \\
\text { How will variability be managed in the future, } \\
\text { particularly as information asymmetry declines? } \\
\text { Are existing theoretical frames sufficient to address } \\
\text { the expanding unit of analysis within service } \\
\text { operations (individuals-groups-systems)? }\end{array}$ \\
& $\begin{array}{l}\text { Technology (techniques and } \\
\text { principles) used to increase } \\
\text { service efficiency and yield. }\end{array}$ & $\begin{array}{l}\text { Technology (techniques and } \\
\text { principles) is used to improve } \\
\text { understanding and automate } \\
\text { processes. }\end{array}$ & $\begin{array}{l}\text { Who manages / governs the automated technology } \\
\text { which delivers elastic services and addresses the } \\
\text { complexity? } \\
\text { What measures (dependent variables) can be used to } \\
\text { understand the nature of service operations in the } \\
\text { future? } \\
\text { Rhat is the role for orchestration in efficiency } \\
\text { improvement of service operations in the future? }\end{array}$ \\
& $\begin{array}{l}\text { Role of technology } \\
\text { the two is clearly separate. } \\
\text { and the boundary between } \\
\text { and technology }\end{array}$ & $\begin{array}{l}\text { Technology assists humans and } \\
\text { the boundary between the two } \\
\text { is beginning to blur. }\end{array}$ & $\begin{array}{l}\text { What role will humans play in the technology- } \\
\text { dominated operations of the future? } \\
\text { What happens when technology replaces humans as } \\
\text { the central actor (e.g., labor intensity, future of work)? } \\
\text { Are there new behavioral entities that require further } \\
\text { theorization (e.g., elastic systems)? }\end{array}$ \\
\hline
\end{tabular}


Table 2. Summary of research issues

\begin{tabular}{|c|c|}
\hline Theme & Research agenda \\
\hline Complexity & $\begin{array}{l}\text { How firms will position themselves in the upcoming connected, } \\
\text { decentralized service ecosystems, where the economic activities of } \\
\text { customers little depend on firms? } \\
\text { How is the nature of complexity changing, and how can future } \\
\text { researchers approach this new context of complex service systems? } \\
\text { How will emerging concepts of complexity affect the design and } \\
\text { operation of service ecosystems? } \\
\text { How elastic, decentralized, and autonomous will the service } \\
\text { systems of the future be? } \\
\text { How will orchestration and governance be managed across } \\
\text { increasingly complex and dynamic networks of collaborators to co- } \\
\text { create value in the future? }\end{array}$ \\
\hline Orchestration & $\begin{array}{l}\text { What normative guidelines can be provided regarding the effective } \\
\text { orchestration and facilitation of value co-creation processes in } \\
\text { complex service systems? } \\
\text { What coordination mechanisms, other than service orchestrators, } \\
\text { are required to optimize complex service ecosystems? } \\
\text { How will automation technologies (e.g., cognitive assistance } \\
\text { systems) assist in the orchestration and facilitation of value for all } \\
\text { stakeholders of service ecosystems? } \\
\text { How to disentangle the roles of actors, other than the lead service } \\
\text { orchestrator, within new platform-based service models? }\end{array}$ \\
\hline Elasticity & $\begin{array}{l}\text { What are the ethical issues associated with the growing presence of } \\
\text { technology within the service ecosystems of the future? } \\
\text { What new institutional forms and approaches to control and } \\
\text { governance (e.g., computers programming computers) are likely to } \\
\text { emerge in the future? } \\
\text { What is the ultimate purpose of complex, self-organizing service } \\
\text { ecosystems: Who do they serve? } \\
\text { Can the systems of the future adequately accommodate elasticity in } \\
\text { the purpose of the systems being created, particularly as these } \\
\text { systems seek to resolve the views of actors with very different } \\
\text { expectations? } \\
\text { How can insights from other disciplines be brought together to } \\
\text { broaden the perspective of computing, and resolve the inherent } \\
\text { tension between the role of technology and other actors? }\end{array}$ \\
\hline
\end{tabular}




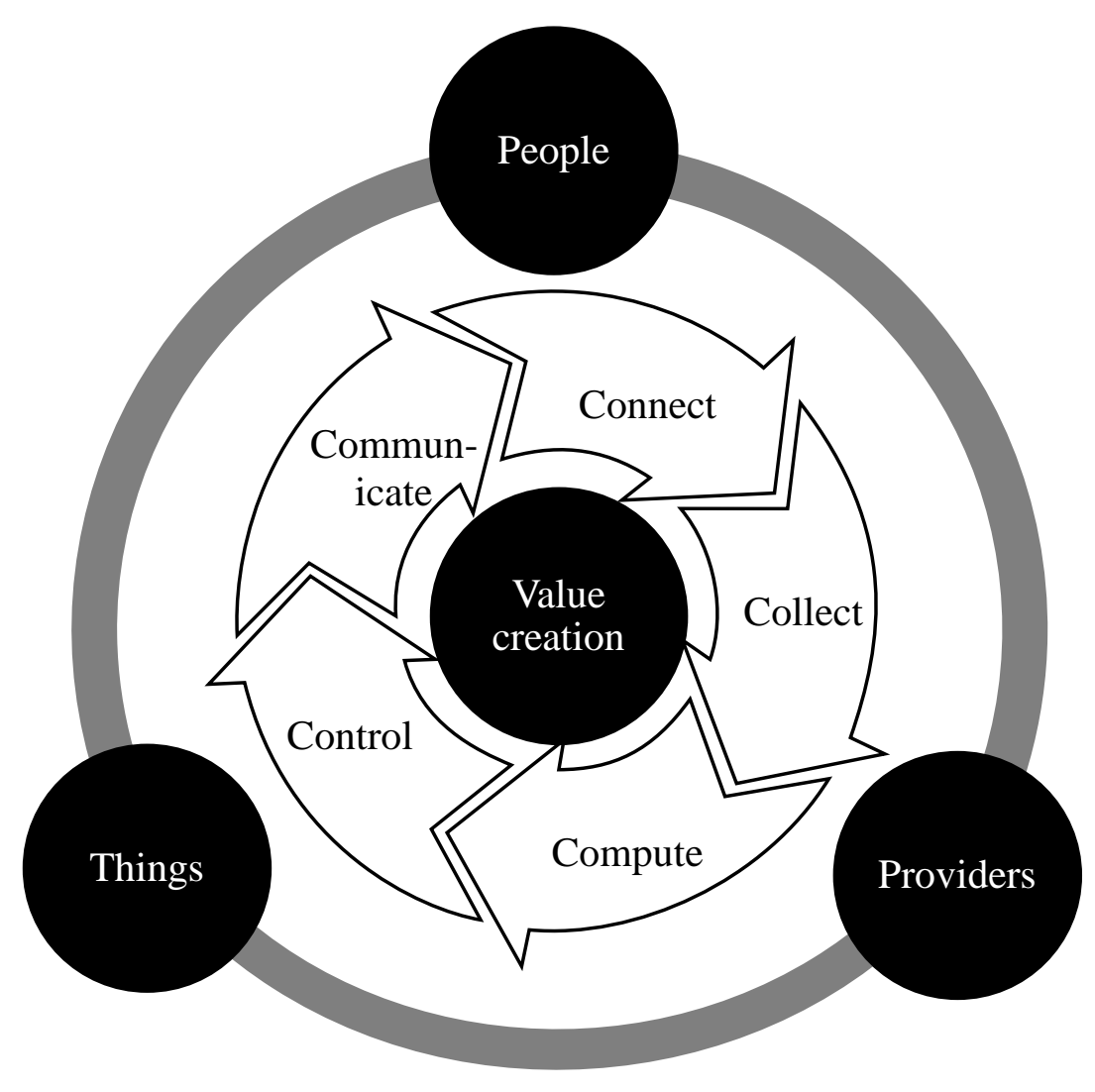

Figure 1. Autonomous service systems (Adapted from Lim and Maglio, 2018)

\section{Biographies:}

Christoph F. Breidbach is a Lecturer (Assistant Professor) at The University of Melbourne in the School of Computing and Information Systems. His publications to date appeared in the Journal of Service Research, Industrial Marketing Management, Managing Service Quality, Service Science, Marketing Theory, and other outlets. He serves on the editorial boards of the Journal of Service Research, Journal of Service Theory and Practice, and the Journal of Business Research.

Sunmee Choi is a Professor of Service Operations at the School of Business at Yonsei University in Seoul, Korea. She holds an M.S. and a Ph.D. from the School of Hotel Administration at Cornell University. The areas of her research interest have been revenue management, service quality management, demand-forecasting methods, distribution channel management, and customer experience management. Her work has been published in journals such as Journal of Business Research, Journal of Service Management, Cornell Hospitality Quarterly, Journal of Hospitality and Tourism Research, International Journal of Hospitality Management, Journal of Marketing Theory and Practice, Journal of Revenue and Pricing Management, and Journal of Hospitality and Tourism Marketing. 
Ben Ellway is an Assistant Professor at the University of Canberra, visiting fellow at Nottingham Trent University, UK, and founder of www.academic-toolkit.com. He completed his $\mathrm{PhD}$ at the University of Cambridge and created the research design canvas, which has been downloaded by students / academics at over 800 universities in 90 countries. His research interests include logics of practice and processes of change and reproduction in market and service systems. His research has appeared in Information Systems Journal, Journal of Service, Management, Marketing Theory, The International Journal of Operations and Production Management, and Journal of Service Theory and Practice.

Byron W. Keating is a Professor in the Research School of Management at the Australian National University. He is also Director of the Service Innovation Lab, a service-focused management and research consultancy based in Canberra, Australia. His research interests are concerned with the role of emerging technologies in supporting the design and delivery of complex services. This interest began with his Ph.D research at the University of Newcastle, and continues today in the areas of social media, location-based services, and big data. His work has been published in journals such as the Proceedings of the IEEE, European Journal of Information Systems, Journal of Supply Chain Management, and the Journal of Service Management.

Katerina Kormusheva is a $\mathrm{PhD}$ Candidate at the College of Business and Economics at the Australian National University. She works in telecommunications in Asia and Australia and owns a farming start-up. Katerina holds a Master's Degree in Economic Sociology from University of Lancaster and a Bachelor's Degree in Business Administration from the American University in Bulgaria. Katerina won the 2015 Professor Malcolm McDonald Academy of Marketing student essay prize.

Christian Kowalkowski is Professor of Industrial Marketing at Linköping University, Sweden, and Research Fellow at Hanken School of Economics, Finland. His research interests include servitization, service growth strategies, service innovation, and solutions marketing. He is associate editor of the Journal of Service Management and Journal of Services Marketing, and an editorial board member for Industrial Marketing Management, Journal of Business Research, Journal of Business \& Industrial Marketing, Journal of Service Research, and Journal of Service Theory and Practice. He is the coauthor of Service Strategy in Action: A Practical Guide for Growing Your B2B Service and Solution Business (Service Strategy Press, 2017).

Chiehyeon Lim is an Assistant Professor in the School of Management Engineering at UNIST (Ulsan National Institute of Science and Technology). He obtained his B.S. and Ph.D. from the Department of Industrial and Management Engineering at POSTECH (Pohang University of Science and Technology). As part of his postdoctoral experience, he served as an assistant project scientist and lecturer in the School of Engineering at University of California, Merced. His research interests include smart service systems, recommendation systems, and analytics in service contexts.

Paul P. Maglio is Professor of Management and Cognitive Science, and Chair of the Department of Management of Complex Systems in the School of Engineering, at the University of California, Merced. He holds a bachelor's degree in computer science and engineering from MIT and a Ph.D. in cognitive science from the University of California, San Diego. One of the founders of the field of service science, Dr Maglio is the Editor-in-Chief of INFORMS Service Science, and the lead editor of the Handbook of Service Science (Volume II will appear in Fall 2018). 